Tez Özeti

\title{
Siyasal İletişimin Amerikanlaşması Bağlamında Ak Parti'nin Siyasal İletişim Çalışmalarının Gazeteler Üzerinden İncelenmesi ${ }^{\star}$
}

\author{
Ahmet Öztekin (Dr. Öğr. Üyesi) \\ Erciyes Üniversitesi İletişim Fakültesi \\ aoztekin@outlook.com \\ ORCID: 0000-0001-7525-2788
}

\author{
Başvuru Tarihi: 16.12.2019 \\ Yayına Kabul Tarihi: 15.01.2020 \\ Yayınlanma Tarihi: 24.01.2020 \\ DOI: http://10.17680/erciyesiletisim.660181
}

\section{Öz}

Bu çalışmada, ABD'nin her alanda ideal bir örnek olarak sunulmasıyla başlayan ve küreselleşmeyle artan Amerikanlaşma olgusu çerçevesinde, siyasal iletişimin Amerikanlaşması ele alınmıştır. 1960'larda Avrupa'daki seçim kampanyalarında görülmeye başlanan ve günümüzde de artarak devam eden siyasal iletişimin Amerikanlaşması olgusunun, dünya genelinde Amerikanvari bir benzeşmeye neden olduğu ve Türkiye'nin de bu benzeşmeden etkilendiği varsayımından hareketle, siyasal iletişimin Amerikanlaşması bağlamında Ak Parti'nin siyasal iletişim çalışmalarının gazetelere yansıması üzerinden bir incelenme yapılmıştır.

Çalışmada, Ak Parti'nin 2002, 2007 ve 2011 genel seçim kampanyalarının gazetelere yansımaları siyasal iletişimin Amerikanlaşması bağlamında değerlendirilmiştir. Yazılı basını temsilen her seçim dönemi için tirajlarına göre ilk üç gazete örneklem olarak seçilmiştir. Buna göre 2002 seçiminde Hürriyet, Posta ve Sabah gazeteleri 18 Eylül 2002 - 2 Kasım 2002 tarihleri arasında, 2007 seçiminde Hürriyet, Posta ve Star gazeteleri 7 Temmuz 2007 - 21 Temmuz 2007 tarihleri arasında, 2011 seçiminde de Hürriyet, Posta ve Zaman gazeteleri 28 Mayıs 2011 - 11 Haziran 2011 tarihleri arası örneklem olarak alınmıştır. Gazetelerdeki haber metinleri, köşe yazıları, makaleler, söyleşiler, röportajlar, fotoğraf yazıları vs. tüm metinler değerlendirmeye dahil edilmiştir.

Çalışmanın amaçları doğrultusunda belirlenen 'Ak Parti' ve 'seçim' anahtar kelimelerinin birlikte geçtiği metinler, örneklem olarak seçilen gazeteler içinde aranmıştır. Yapılan araştırma sonucunda 'Ak Parti' ve 'seçim' anahtar kelimelerinin birlikte geçtiği toplam 1045 metin tespit edilerek, inceleme bu 1045 metin üzerinden gerçekleștirilmiștir. Analiz sonucu elde edilen veriler, siyasal iletişimin Amerikanlaşmasındaki kriterler olarak belirlenen profesyonelleştirilme, bilimselleştirilme, kişiselleştirilme, medyatikleştirilme, kitle partileri ve depolitizasyon ana başlıkları altında değerlendirilmiştir.

Gazete metinlerinin incelenmesi sebebiyle içerik analizi ve söylem analizi çalışmanın yöntemleri olarak seçilmiştir. Analiz sonucu gazete metinlerinden elde edilen veriler, siyasal iletişimin Amerikanlaşması çerçevesinde niceliksel ve niteliksel bir yorumlama ile açıklanmıştır. Yapılan inceleme ve değerlendirmeler sonucunda Ak Parti'nin siyasal iletişim kampanyalarında siyasal iletişimdeki Amerikanlaşmayı gösteren kriterlerin tamamının mevcut olduğu ve bunların gazete metinlerine yansıdığı tespit edilmiştir.

Anahtar Kelimeler: Siyasal iletişim, Siyasal iletişimin Amerikanlaşması, Ak Parti, 2002 Genel Seçimi, 2007 Genel Seçimi, 2011 Genel Seçimi.

\footnotetext{
* Bu çalışma, Erciyes Üniversitesi Sosyal Bilimler Enstitüsü’ne 2013 yılında sunulan “Siyasal Illetişimin Amerikanlaşması Bağlamında Ak Parti’nin Siyasal IIletişim Çalışmalarının Gazeteler Üzerinden İncelenmesi” başlıklı doktora tez özetidir.
} 


\title{
The Review of the AK Party's Political
}

\section{Communication Studies on the Newspapers in the Context of Americanization of Political Communication}

\author{
Ahmet Öztekin (Asst. Prof. Dr.) \\ Erciyes University Faculty of Communication \\ aoztekin@outlook.com \\ ORCID: 0000-0001-7525-2788
}

Date Received: 16.12.2019

Date Accepted: 15.01.2020

Date Published: 24.01.2020

DOI: http://10.17680/erciyesiletisim.660181

\begin{abstract}
In this study, the Americanization of political communication is analysed within the framework of the phenomenon of Americanization, which started with the presentation of the USA as an ideal example in every field and increased with globalization. The phenomenon of the Americanization of political communication, which started to be seen in the European election campaigns in the 1960s and continues to increase today, given that this phenomenon causes American style a similarity throughout the world and that the assumption that when Turkey is also affected by this analogy, an analysis was performed on the reflection of the Ak Party's political communication efforts to the newspapers, in the context of the Americanization of political communication.
\end{abstract}

The reflections of Ak Party's 2002, 2007 and 2011 general election campaigns on newspapers were analyzed in this study. As representing the printed press, the first three newspapers were chosen as samples for each election period. Accordingly; it was taken as a sample; Hürriyet, Posta and Sabah newspapers between 18 September 2002 and 2 November 2002 in the 2002 election; Hürriyet, Posta and Star newspapers, between 7 July 2007 and 21 July 2007, in the 2007 election; Hürriyet, Posta and Zaman newspapers, between 28 May 2011 and 11 June 2011, in the 2011 election. In the evaluation, all of the news reports, columns, articles, interviews, conversations and photo writings in the newspapers were included.

For the purposes of the study, the keywords of 'Ak Party' and 'election' texts which used together were searched in the selected newspapers. At the end of the search, a total of 1045 texts were identified, which consisted of 'Ak Party' and 'election' keywords, and the analysis was performed on these 1045 texts. The data obtained as a result of the analysis were evaluated under the headings of professionalization, scientificization, personalization, mediaisation, mass parties and depoliticization, which were determined as the criteria in the Americanization of political communication.

Because of the investigations of newspaper texts; content analysis and discourse analysis were chosen as the methods of the study. The data obtained from the newspaper texts as a result of the analysis were explained with a quantitative and qualitative interpretation within the framework of the Americanization of political communication. As a result of the analyses and evaluations, it was seen that all of the criteria that showed Americanization in political communication existed in Ak Party's political communication campaigns and these were reflected in the newspaper texts.

Keywords: Political Communication, Americanization of the Political Communication, Ak Party, 2002 General Election, 2007 General Election, 2011 General Election. 


\section{Giriş}

İnsanlar duygu ve düşüncelerini ifade ederek, paylaşarak sosyalleşmekte, günlük yaşam pratiklerini ve deneyimlerini birbirlerine aktararak toplumsallaşmaya çalıșmaktadır. Sosyal bir varlık olan insanın, toplum içinde bir arada yaşama zorunluluğu, bazı toplumsal kuralların ortaya çıkmasına neden olmuş, söz konusu bu kurallar zamanla, toplumsal denetimi ve kontrolü zorunlu kılarak 'siyaset' kavramını ortaya çıkarmıştır. Toplumsal yaşam içinde elde edilen tüm ortak girdi ve çıktıların, tek merkezden yönetilmesi ihtiyacının yanı sıra, toplumsal kaynakların denetimi ve dağıtımında ortaya çıkan sorunlar, 'siyasal iktidar' düşüncesini pekiştirmiştir. Böylelikle, yönetenle yönetilen arasında bir ilişki ortaya çıkmış ve bu ilişkinin yönetimi, tarih boyunca tartışıla gelen önemli bir sorunsalı oluşturmuştur.

İnsanlık tarihi kadar eski olan yöneten-yönetilen ilişkisindeki egemen olma yarışı, zamanla kişiler/gruplar arasında planlı faaliyetler çerçevesinde sürdürülen bir iktidar mücadelesine dönüşmüștür. Bu iktidar mücadelesinde, dönemin şartlarına göre farklı şekillerde ortaya çıkan ödül ve ceza yöntemleri sıklıkla kullanılmıştır. Zamanla siyasete dair elde edilen tecrübeler ve toplumsal yapıdaki değişiklikler, siyasetteki yöntem ve enstrümanları da niceliksel ve niteliksel olarak değiștirerek siyasetin yeni bir boyuta taşınmasına neden olmuştur. Böylelikle yöneten-yönetilen ilișkisinde, yeni bir başlık olarak 'siyasal iletişim' kavramı ortaya çıkmıştır. Siyasal iletişimi geniş bir çerçevede ele aldığımızda belirli kişi, grup ya da grupların siyasal avantaj sağlamak amacıyla diğer kişi grup ya da grupların beklenen/istenen yönde siyasal hayata katılarak siyasal davranışlar sergileyebilmesini hedefleyen planlı programlı yöntemler bütünü șeklinde değerlendirmemiz mümkündür.

Antik Yunandan bugüne kadar, günün koşullarına göre sürekli bir değişim ve gelişim içinde bulunan siyasal iletişim çalışmaları, günümüzde ağırlıklı olarak kitle iletişim araçları üzerinden gerçekleștirilmektedir. Siyasal iletişim açısından kitle iletişim araçları, kamunun kanaatlerini yönlendirici bir güç olması (kamuoyu oluşturması) ve çeşitli yayın formatlarıyla (gazete, dergi, televizyon, internet, sosyal medya vs.) bireylere günlük yaşantıları içinde pek çok şekilde ulaşarak mesajlarını düzenli ve devamlı iletebilecek bir yapıda olması sebebiyle büyük önem ifade etmektedir. Günümüzde bir kampanya ne kadar kitle iletişim araçları merkezli tasarlanırsa, o kadar seçmene ulaşabilme ve ikna edebilme, dolayısıyla da başarılı olabilme imkanına sahip olmaktadır. Bu nedenle daha fazla sayıda seçmene ulaşabilmek adına siyasal iletişim stratejileri medyayla aracılanmış bir yapıya bürünmekte ve siyasetçileri de seçmenle olan iletişimlerini ağırlıklı olarak kitle iletişim araçları üzerinden gerçekleștirmeye zorlamaktadır.

Dünya Savaşlarından sonra büyük bir güç olarak ortaya çıkan ABD, 1990'da Soğuk Savaş’ın da bitmesiyle dünya liderliğini üstlenerek tüm dünyada egemen bir güç ve kültür haline gelmiştir. Küreselleşmenin her geçen gün artan bir hızla devam etmesi, ABD’nin de küreselleşmenin öncü gücü olarak kendini ekonomik, siyasi, askeri ve kültürel anlamda ideal bir örnek olarak sunması, dünya genelinde bir Amerikanlaşma sürecinin yaşanmasına neden olmaktadır. Söz konusu Amerikanlaşmanın etkisi, siyasal iletişim alanında da yoğun bir şekilde kendini hissettirmekte, dünya genelindeki siyasal iletişim çalışmalarının giderek ABD'deki kampanyalara benzediği görülmektedir. ABD'deki siyasal iletişim çalışmalarındaki görece zenginlik ve hareketlilik, farklı ülkelerdeki siyasetçilerin de ilgisini çekmekte, ülkelerdeki farklı siyasal, kültürel ve sosyal yapılara rağmen, dünya genelinde siyasal iletişim çalışmalarının giderek Amerika'daki 
kampanyalara benzemesiyle, siyasal iletişim alanında da bir Amerikanlaşmanın yaşandığı görülmektedir.

$\mathrm{Bu}$ anlamda halkla ilişkiler, reklamcılık, pazarlama ve propaganda gibi yöntemlerin kampanyalara hakim olması, kampanyalarda bilimsel ve teknik bilgilere sıkça başvurulması, seçimlerde partili yandaşlar yerine profesyonel danışmanların/ajansların görev alması ve bu profesyoneller tarafından hazırlanan stratejilerin kitle iletişim araçları aracılığıyla yayılması, yine medya aracılığıyla oluşturulan imajlarla liderlerin partilerden ve politikalardan daha önemli olarak konumlandırılması, siyasal aktörlerin kitle iletişim araçlarında sürekli boy göstermesi ve siyasetçilerin medya tarafından yıldızlaştırılarak popülerleştirilmesi, gücü nedeniyle medyanın seçimlerde birinci derecede rol oynaması ve kampanya stratejilerinin bu doğrultuda oluşturulması, Amerikan tarzı siyasal iletişim çalışmalarının karakteristik özellikleri olarak karşımıza çıkmaktadır. Söz konusu karakteristik özellikleri taşıyan siyasal iletişim çalışmalarının farklı ülkelerde uygulanmasıyla da dünya genelindeki siyasal iletişim çalışmaları giderek benzeşmekte yani Amerikanlaşmaktadır. Bugün için farklı ülkelerdeki birçok seçim kampanyası, ABD seçimlerindeki siyasal kampanyaların birer yansıması olarak değerlendirilmektedir. Bahsedilen bu benzeșme/Amerikanlașma, ilk olarak 1960'larda Avrupa ülkelerinde ortaya çıkmış ve günümüzde dünya geneline yayılmıştır.

Türkiye'de yaşanan Amerikanlaşma sürecini siyasal iletişim çerçevesinde ele aldığımızda da benzeşmelerin olduğu görülmektedir. Siyasal iletişimde 1977 seçimiyle birlikte profesyonel çalışmaların artması, bu çalışmalarda kitle iletişim araçlarının kullanılması, bilimsel ve teknik bilgiye dayalı stratejilerin hazırlanması, kampanyaların birer şova dönüştürülerek liderlerin starlaştırılması, profesyonelleşmeyle birlikte kampanya masraflarının artması, Türkiye'deki siyasal iletişim çalışmalarındaki Amerikanlaşmanın birer sonucu olarak karşımıza çıkmaktadır.

Türkiye'deki siyasal iletişim çalışmalarında bir dönüşümün yaşandığı varsayımından hareketle, çok partili hayata geçiş sonrasında en uzun süre tek başına iktidar olan Ak Parti'nin siyasal iletişim kampanyalarının ABD'deki gibi bir seyir izleyip izlemediği, yani Amerikanlaşıp Amerikanlaşmadığına dair değerlendirmelerin yapılması bu çalışmanın temel amacını oluşturmaktadır.

Türkiye'de, siyasal iletişim üzerine çok sayıda çalışma yapılmasına karşın, siyasal iletişimdeki Amerikanlaşmayı inceleyen akademik çalışmaların sayısı oldukça azdır. $\mathrm{Bu}$ nedenle, siyasal iletişimin Amerikanlaşmasını ele alan bu çalışmanın, alana doğrudan bir katkısının olacağı düşünülmektedir. Yapılan az sayıdaki siyasal iletişimin Amerikanlaşması çerçevesindeki çalışmalar, genellikle tek bir seçim dönemini incelemesi nedeniyle dönemler arası kıyaslamalara imkân vermemektedir. Bu çalışma ise üç genel seçim dönemi kampanyalarını ayrı ayrı incelemiş olması, dönemler arası kıyaslama yapılabilecek verileri sunması ve Amerikanlaşmanın farklı seçim dönemlerindeki seyrini ortaya koyması noktalarında diğer çalışmalardan ayrılmaktadır.

Siyasal iletişimin Amerikanlaşması olgusu, kitle iletişim araçlarının kamusal olayların yer aldığı önemli bir mecra olduğu ön kabulünden hareketle, kampanyaların yayılmasını, duyurulmasını sağlayan, siyaset kurumuyla seçmen arasında bir köprü olarak iletileri taşıyan bir mecra olarak medya üzerinden incelenmiştir. Bu çerçevede gazeteler gerek haber metinlerine ulaşabilme kolaylığı gerekse seçimleri yansıtabilme gücü dikkate alınarak çalışma için medyayı temsilen tercih edilmiştir. Ayrıca siyasi partilerin ve liderlerin, özellikle seçime az bir süre kala, farklı görüşlerden seçmenlerin okuduğu 
yüksek tirajlı gazetelerde yer alma çabaları, gazetelerin partiler/liderler için önemli bir kitle iletişim aracı olduğunu göstermesi açısından da önemlidir. Bununla birlikte her ne kadar Yüksek Seçim Kurulu'nun 16.03.2011 tarihli 203 sayılı kararıyla, 2011 seçiminde televizyonlarda partilere ve adaylara ait siyasi reklamlara izin verilmiş olsa da yine YSK kararları gereği 2002 ve 2007 seçim dönemlerinde siyasal partilere ve adaylara ait reklamların özel radyo ve televizyon kuruluşları tarafından yayınlamasının yasaklaması, siyasal partilerin reklam amacıyla gazetelere yönelmesine ve gazetelerle daha sıkı ilişkiler kurmasına neden olmuştur. Dolayısıyla partilerle/siyasetçilerle gazeteler arasındaki ilişkilerin artması, gazeteleri siyasal kampanya ve haberlerin duyurulması/yayılması ve üretilmesi anlamında son derece önemli hale getirmiștir.

Gazete metinlerinde yer alan rutin seçim haberlerin yanı sıra köşe yazılarında, sokak röportajlarında, söyleşilerde, okuyucu mektuplarında, uzman görüşlerinde her kesimden bireyin/seçmenin/okurun görüş belirtebiliyor olması, farklı kesimlerdeki bu seçmenlerin kendilerine iletilen mesajları değerlendirme ve yorumlama imkanına gazeteler aracılığıyla kavuşabiliyor olması, kampanyaların seçmen tarafından nasıl algılandığının tespit edilebilmesi adına da önemli bilgiler sunmaktadır. $\mathrm{Bu}$ bağlamda gazete metinlerinde gazetecilerden ünlülere, seçmenlerden siyasetçilere kadar farklı görüş ve söylemlerin yer alması; gazetelerin seçim sürecinde hem siyasal söylemlerin, kampanyaların yansıdığı hem de bu söylemler ve kampanyalar çerçevesinde seçmen değerlendirmelerinin yer aldığı ortak bir mecra haline gelmesi nedeniyle gazete metinleri bu çalışmada inceleme nesnesi olarak tercih edilmiştir.

Çalışmada, yaygın basını temsilen seçim dönemlerindeki fiili satış rakamları doğrultusunda ilk üçe giren gazeteler örneklem olarak seçilmiştir. Bu gazeteler, daha fazla okuyucu tarafından tercih edilmesinin yanında, siyasal kampanyalara dair daha fazla sayıda haber barındırdıkları varsayımından hareketle, Amerikanlaşmaya dair kriterlerin saptanmasını daha kolay hale getireceği düşüncesiyle tercih edilmiştir. $\mathrm{Bu}$ anlamda gazetelere ait fiili satış rakamları, Basın Takip Merkezi'nden alınmıștır. Çalışma çerçevesinde seçim yılına göre, 2002 seçimi için Hürriyet, Posta ve Sabah gazeteleri 18 Eylül 2002 - 2 Kasım 2002 tarihleri arasında, 2007 seçimi için Hürriyet, Posta ve Star gazeteleri 7 Temmuz 2007 - 21 Temmuz 2007 tarihleri arasında, 2011 seçimi için Hürriyet, Posta ve Zaman gazeteleri 28 Mayıs 2011 - 11 Haziran 2011 tarihleri arasında örneklem olarak alınmıştır. Seçilen gazetelerdeki siyasal haberler, köşe yazıları, makaleler, röportajlar, söyleşiler, okuyucu mektupları ve fotoğraf yazıları gibi her türlü metin Amerikanlaşma çerçevesinde incelenmiştir. Yapılan çalıșmada, siyasal iletişimin Amerikanlaşmasının gazetelere yansıması üzerinden bir incelenmenin yapılması sebebiyle, gazetelerde yer alan siyasal partilere ve adaylara ilişkin ilanlar ve reklamlar dikkate alınmamıştır.

Çalışmanın amaçları doğrultusunda belirlenen 'Ak Parti' ve 'seçim' anahtar kelimeleri örneklem olarak seçilen gazete metinleri içerisinde aranmıştır. Yapılan arama sonucunda 'Ak Parti' ve 'seçim' anahtar kelimelerini birlikte içeren toplam 1045 metin tespit edilmiş ve inceleme bu 1045 metin üzerinde gerçekleştirilmiştir. Tespit edilen 1045 metin içerik ve söylem analizi yöntemiyle değerlendirilmiş ve Ak Parti ile ilgili iletiler, Amerikanlaşma unsurları konularına göre gruplandırılmıştır. Söz konusu metinlerin içeriğine bakılarak, Ak Parti kampanyalarındaki Amerikanlaşmanın tespitine yönelik analizler yapılmıştır. Analiz sonucu gazete metinlerinden elde edilen veriler, siyasal iletişimin Amerikanlaşması çerçevesinde niceliksel ve niteliksel bir yorumlama ile açıklanmaya çalışılmıştır. 


\section{Siyaset ve Siyasal Hayat}

Siyasete ve siyasal konulara eğilmiş, bu alanda önemini günümüze kadar koruyan yapıtlar vermiş olan düşünürlere Antik Yunan'dan başlayarak rastlanmasına karşın, yakın döneme kadar siyaset konusuna ilişkin çalışmalar felsefi bir yaklaşımdan öteye geçememiştir. Siyasal düşünceler tarihinin çok eskilere kadar uzanmasına rağmen, siyasal olaylara toplum bilimsel bakış ise oldukça yenidir (Kışlalı, 1997, s. 22). Aristo'dan başlayarak Platon'a doğru bir gelişme çizgisi izleyen siyasetin kavramsallaştırılma çabası, Machiavelli'de önemli bir aşamaya ulaşmış, Rönesans'la birlikte söz sanatlarının da gelişmesiyle daha da önemli hale gelmiştir (Tokgöz, 2008, s. 240). Bu çerçevede siyaset bilimi Aristotales'ten İbni Haldun'a, Machiavelli'den Maltus'a kadar sürekli bir gelişim sergilemiştir.

Toplumlarda siyaset olgusunu ortaya çıkaran temel faktör, insanların sosyal gruplar olarak toplu halde yaşamalarıdır. Eğer her birey tek başına ve başkasıyla etkileşim halinde bulunmaksızın yaşayabilseydi, siyaset de söz konusu olmazdı. Çünkü siyasete dair her tanım, siyaseti ortak yaşamın bir sonucu olarak sunmakta, bu birlikte yaşama zorunluluğu, devlet şeklinde bir siyasal örgütlenmenin yanında iktidar olgusunu da doğurmaktadır. Toplumsal hayat, insanların farklı roller üstlenmesini, birbirinden farklı statüleri işgal etmelerini, değerlerin üretimi sürecine katılmalarını, üretilen değerlerin bölüşülmesi hususunda bir mücadelenin verilmesini, bütün bunları yaparken karşılıklı bir etkileşimin kurulmasının alt yapısını da oluşturmaktadır. Birlikte yaşamak, insanlar arasında karşılıklı etkileşimi ve bu etkileşim sürecinde pek çok değerin üretilip belli biçimlerde bölüştürülmesini zorunlu hale getirmektedir (Dursun, 2004, s. 31-32; Akdoğan, 1995, s. 21).

Siyaseti tanımlama çabalarındaki çelişkili duruma değinen Duverger (1964, s. 10-11), insanların politika üzerine düşünmeye başladığından beri, politikayı birbirine zıt iki yorum tarzında ele aldığının altını çizmektedir. Roma tanrısı Janus'un iki yüzü üzerinden bir anlatım yapan Duverger, iktidarı elinde tutan grup ya da fertlerin toplum üzerindeki egemenliğini bir mücadele, bir çatışma olarak değerlendirerek tanrı Janus'un bir yüzüne; iktidarın düzeni ve adaleti hakim kılmasıyla oluşan uzlaşmayı da tanrı Janus'un diğer yüzüne benzeterek birbiriyle çelișen tanımları tek bir bedende toplayabilmiştir. $\mathrm{Bu}$ bağlamda siyaset ya bireysel menfaatlerin genelin/kamunun menfaatlerinin önüne geçmesini engelleyecek ve toplumsal uzlaşıyı sağlayacak ya da azınlığı çoğunluk üzerinde hakim kılacak ve çatışmayı artıracaktır. Bu anlatım doğrultusunda Janus'un bir yüzüyle politika, azınlığın çoğunluk üzerindeki tahakkümünü ve imtiyazını sürdürmesini sağlarken; diğer yüzündeki politika ise fertlerin topluluk içinde birleşmelerini, kaynaşmalarını sağlayarak Aristotales'in bahsettiği adil siteyi kurmak için gerekli olan bir araç olarak karşımıza çıkmaktadır.

Siyaset, siyasal hayat, siyasal iletişim gibi kavramlardan bahsedildiğinde akla her ne kadar demokratik sistemler gelse de iktidar örgütlenmesinin bulunduğu her türlü sistemde, siyasal iletişimden bahsetmek mümkündür. Demokratik sistemlerde tarafların açık ve karşılıklı olarak yaptığı siyasal iletişim faaliyetleri, antidemokratik sistemlerde yönetici erkin tekelinde olmakla birlikte, toplumu depolitize eden tek yönlü bir ikna sürecine hazırlamak amacıyla kullanılmaktadır.

Günümüzde siyaset, iletişimsel bir boyutta cereyan etmektedir. Kitle iletişimi vasıtasıyla iletilen (sözel, sembolik, göstergesel) politik söylem olmasaydı, çok sınırlı bir kapsam alanında gerçekleşebilen bir politik süreçten ve siyasal bilinçten bahsedilebilirdi (Oktay, 
2002, s. 24). Gerçek demokrasinin enformasyon ve iletişim olmadan var olamayacağı yaygın bir biçimde kabul edilmektedir. Herhangi bir demokrasinin gelişebilmesi için yurttaşların kamusal etkinliklere katılımını sağlaması gerekmektedir. Başka bir ifadeyle, yurttaşlar ve kurumlar kendilerini kamu önünde ifade edebilmeli ve doğru enformasyon edinebilmelidir. Böylece, medya aracılığıyla sürdürülen enformasyon ve iletişim, siyasetin alanını genişletmektedir (Encabo, 2002, s. 443). Bu anlamda demokrasi düşüncesi, modern dünyada yaygın destek görmeye başladığı andan itibaren, siyasetin kitle iletişim araçları üzerinden yapılması kaçınılmaz bir hal almıştır (Meyer ve Hinchman, 2002, s. 69).

\section{Siyaset ve Siyasal İletişim}

Siyasal iletişim, siyasal süreçlerle iletişim süreçleri arasındaki ilişkileri ele alan araştırmalardan oluşan akademik bir alandır. İletişimin siyasal konular hakkındaki kamusal bilgiyi, insanların inançları ile eylemlerini etkileyecek şekilde stratejik bir biçimde kullanması, siyasal iletişim alanının gelişmesindeki temel etkeni oluşturmaktadır (Mutlu, 2004, s. 256-257). Bu alandaki çalışmaların temelinde ağırlıklı olarak psikoloji, siyaset bilimi ve iletișim yatmaktadır. Bu bağlamda siyasal iletişim, siyasal mesajlara tepki veren insan davranışlarıyla birlikte siyasal konular üzerine çalışmaktadır (Graber and Smith, 2006, s. 487). Çağımızda siyasal iletişimle ilgili çalışmaların yoğunluk kazanması, İkinci Dünya Savaşı'ndan sonra, dünya siyasal arenasında görülen büyük değişikliklere paralel olarak kendini göstermeye başlamış, genel oy ilkesinin evrensel ölçüde kabul görmesi, seçmenleri seferber edebilen kitlesel siyasal partilerin, baskı ve çıkar grupları ile kitle iletişim araçlarının çeşitlenerek yaygınlaşmasıyla da devam etmiştir (Tokgöz, 2008, s. 98-99).

Çok partili siyasal yaşam içinde yönetenler ve yönetilenler arasındaki iletişim biçimleri kökten denebilecek değişikliklere uğramıștır. Yönetime aday olanların iktidar olabilmeleri, seçmenin ikna edilmesine yani seçmenin gönüllü desteğine, rızasına bağlıdır. Günümüz koşullarında seçmenlerle kurulacak iletişimde, siyasal adayların ya da partilerin hedeflerine ulaşabilmeleri bilimsel ve planlı bir çerçeveyi zorunlu kılmaktadır (Uztuğ, 1996, s. 844). Bu bağlamda seçmenin kanaatini, düşüncesini, fikrini, iradesini, desteğini ya da tepkisini oy olarak ifade edebileceği her türlü seçme işleminde; aday kişi, grup ya da partilerce seçmenin beklentiler doğrultusunda tutum/davranış gerçekleştirebilmesi için ikna edilmesini esas alarak yürütülen planlı programlı tüm faaliyetlere siyasal kampanya denilmektedir. Siyasal iletişim, demokratik bir siyasal sistemin merkezi sürecine dahil olarak, siyasal aktörlerin performansını ve demokrasinin kalitesini kesin bir şekilde etkilemektedir. Bu temel demokratik siyasal sürecin, ana dinamiğini yakalamak için adaylar, medya ve seçmen arasında; partiler de siyasete ilgi duyan diğer siyasal oyuncular arasında iletişimin kurulması görevini üstlenmektedir (Buchanan, 2005, s. 362). İletişim bu nedenle siyasetin ana damarını oluşturmaktadır. Siyaset, tıpkı iletişim gibi tek başına yapılabilen bir eylem değildir. Her ikisinde de birden fazla kişiye ihtiyaç duyulmaktadır. Her iki kavram da kitlelere seslenmektedir. Siyaset, iletişimi bir araç olarak kullanmakta, amaçlarını gerçekleştirmek için ondan yararlanmaktadır (Özkan, 2007, s. 18). İletişimi, sembolik formların üretimi, aktarımı, alımlanması ve değişik türdeki kaynakların idaresini içeren toplumsal bir faaliyet (Thompson, 2008, s. 37) olarak değerlendirdiğimizde, siyaseti ve iletişimi birbirinden ayırmak imkânsız hale gelmektedir. Bu noktada kitle iletişim araçlarının, demokratik politik sistemde, toplumsal kesimlerin taleplerini ve kanaatlerini iktidar sahiplerine; iktidar sahiplerinin icraatlarını, görüşlerini ve vaatlerini de kamuoyunu oluşturan toplumsal kesimlere tarafsız olarak 
aktarması suretiyle, çift yönlü politik iletişimin gerçekleştirilmesini sağladıkları egemen görüş tarafından varsayılmaktadır (Oktay, 2002, s. 4-5).

Reklamcılık tekniklerinin, kamuoyu yoklamalarının, televizyonların ve afişlerin seçim kampanyalarında yer almaya başlamasıyla ortaya çıkan siyasal iletişim kavramı, özellikle 1952'deki Eisenhower'ın kampanyasından sonra reklam, halkla ilişkiler ve pazarlamadan büyük ölçüde etkilenmiştir. Bu teknikler ilk olarak İkinci Dünya Savaşı'ndan sonra Amerika'da doğarak gelişmiş ve 1960'lı yıllarda da Batı Avrupa ülkelerinde kullanılmaya başlanmıștır (Novotny, 2000, s. 12; Topuz, 1991, s. 7).

\section{Siyasal İletişimin Amerikanlaşması}

Değişmeyen tek şeyin değişimin kendisi olduğu dünyamızda, düşünceler, ideolojiler, anlamlar ve algılamalar da sürekli olarak değişmektedir. Beğenilenle beğenilmeyen bir günde yer değiştirebilmekte, en katı alışkanlıklar bile tersine dönebilmektedir. Değişim kavramıla birlikte değişimin getirdikleri de önem kazanmaktadır. Sanayi Devrimi sonrasındaki modernleşme süreci, yeni ekonomik yapılanmaları ve bireyler arasındaki yeni sınıflaşmayı da beraberinde getirmiştir. Bu yeniliklerden liberalizm belirleyici bir güç olarak ortaya çıkmış, McLuhan'ın ifadesiyle "küreselleşen köyde" güçlü, değiştirici bir rol oynamaya başlamıştır. Liberalizmin lokomotiflerinden Amerika Birleşik Devletleri de söz konusu değişimle birlikte, küresel bir güç haline gelmiştir. ABD, birçok noktada 'lider ve örnek' olarak diğer ülkelere rol model olmuş, özellikle İkinci Dünya Savaşı sonrası döneme siyasi, askeri, ekonomik ve kültürel anlamda damgasını vurarak lider ülke konumuna gelmiştir.

Günümüzün 'süper gücü' olarak nitelenen ABD siyasi, askeri ve ekonomik anlamda rol model olarak algılanmakta ve sunulmaktadır. Aslında bu şekilde bir sunum, bizatihi Amerika'nın kendisi tarafından yapılmaktadır. ABD, her ne kadar bugün için dünya üzerinde büyük bir güç olsa da güç gösterinin kendisindedir. Gerek idari yapılanmalar gerekse bilimsel yapılanmalar, genellikle ABD örneklemi üzerinden gerçekleşmektedir (Baudrillard, 1996). ABD’nin bütün dünyada rol model olarak, sözü edilen benzeşmenin ortak paydası olması, her şeyin kaçınılmaz bir şekilde Amerikanlaşmasına neden olmaktadır. $\mathrm{Bu}$ benzeşmeyi ve benzeşme sonrası ortaya çıkan taklitleri eleştiren Baudrillard (s. 90-93), Amerika'yı modernliğin ve çağdaşlı̆̆ın özgün versiyonu olarak nitelerken, diğer ülkeleri ise birer dublajlı, alt yazılı kötü kopyaları olarak değerlendirmektedir.

Siyasal iletişimin özellikle Avrupa'da Amerikanlaşmasından söz edilmektedir. Türkiye'nin de Avrupa'nın bir parçası, Amerika'nın bir müttefiki olarak bu durumdan etkilendiğini söylemek mümkündür. Pek çok yazar, siyasal iletişimde Amerikanlaşmanın İngiltere, Fransa, Hollanda, Yunanistan, İtalya ve bazı İskandinav ülkeleri gibi birçok Avrupa ülkesinin yanı sıra, Latin Amerika ülkelerinde de görüldüğ̈̈nü belirtmektedir (Negrine and Papathanassopoulos, 1996; Hallin and Mancini, 2004; Lilleker, 2006; Norris, 2003, s. 10). Örneğin ilk olarak ABD'de başlayan paralı siyasal reklamlar, daha sonra Avrupa ülkelerine de yayılmış (Aziz, 2007, s. 75), benzer bir durumun siyasal pazarlamada yaşanmasıyla da bu alanın Amerikanlaşması ve ticarileşmesine ciddi eleştiriler getirilmiştir (Odabaşı, 2009, s. 35). Mattelart da (1995, s. 61), benzer bir şekilde reklam ve pazarlama tekniklerini Amerika'nın yaptığı en başarılı ihracat olarak görmekte, bu durumu 'adplomacy' (advertisement-diplomacy) olarak nitelendirmektedir. Siyasal iletişimdeki Amerikanlaşma eğilimi sadece ABD’deki çalışmaların güçlü etkilerinin Avrupa ülkelerinde hissedilmesinden değil, aynı zamanda Amerikan egemenliğindeki/ 
kontrolündeki uluslararası iş birlikleri, paralel örgütlenmeler ve diğer uluslararası kurumsal yapılardan da kaynaklanmaktadır.

Bütün bu anlatılanlarla birlikte siyasal iletișimin Amerikanlaşmasında genel anlamda bir görüş birliği olsa da hangi kriterlerin, faktörlerin ve uygulamaların siyasal iletişimde Amerikanlaşmaya neden olduğu, yani neye göre Amerikanlaşmanın gerçekleştiği noktasında net bir görüş birlikteliği bulunmamakta, bu konu üzerine yapılmış akademik çalışmalarda farklı kriterlere rastlanmaktadır. Yapılan incelemeler sonucunda Amerikanlaşma kriterlerinin farklı isim ve başlıklar altında ele alınmasına karşın, içeriklerinin büyük ölçüde benzer olduğu görülmüştür. Bu noktada Mancini ve Swanson (1996), siyasetin kişiselleşmesi, siyasetin bilimselleşmesi, partilerin yurttaşlara ilgisiz kalışı ve bağların kopması, iletişimin bağımsız yapıları, yurttaşlıktan izleyiciliğe geçişi siyasal iletişimin Amerikanlaşmasında kriter olarak ele alırken; Holtz-Bacha (2002, s. 24) sadece profesyonelleşme ve ideolojisizleştirmeyi kriter olarak ele almıştır. Herz ve Weischenberg ise Holtz-Bacha'nın profesyonelleşme ve ideolojisizleştirme başlıklarına negatif kampanyaları, siyasi ayrılıkları (siyasal çözülmeler), depolitize olmuş bireyleri de ekleyerek genişletmiştir (Herz ve Weischenberg, 1998, aktaran Holtz-Bacha 2002, s. 24). Ansolabehere ve Iyengar ise (1997), saldırı türündeki negatif siyasal kampanyalara dikkat çekmiştir. Köker ve Kejanlıoğlu ise (2004, s. 41-43) bilimselleşme/teknikleşme, kişiselleşme, alışıldık ve belirgin siyasal parti-yurttaş bağının yerine esnek ve değişken medya-tüketici/seyirci/yurttaş bağının geçmesi ve medyanın politik güç merkezi olması șeklinde konuya yaklaşmaktadırlar. Oktay da (2002, s. 25), kampanyalardaki imaj faktörünün ön plana çıkması, medyanın seçimlerde birinci derecede rol oynaması, artan kampanya masrafları, seçim kampanyalarının profesyonelleşerek danışmanların ve uzmanların kampanyaların vazgeçilmezi olması, siyasal reklamların etkinliğinin artması şeklinde sıralama yapmıştır. Tokgöz (2008) ise Amerikanvari seçim kampanyalarının temel öğelerini iletişim biçimi yönünden değerlendirerek kişisel iletişim ve kitle iletişimi olarak iki başlıkta incelemiştir.

$\mathrm{Bu}$ çalışmada ise yukarıda belirtilen inceleme sonucunda ulaşılan Amerikanlaşma kriterleri, birbirleriyle ilişkilendirilerek 5 ana başlık altında toplanmıştır. Siyasetin teknikleşmesi ve bilimselleşmesi 'siyasetin bilimselleștirilmesi' başlığı altında; imaj faktörü ve kişiselleşme 'siyasetin kişiselleştirilmesi' başlığı altında; medyanın kampanyalarda birinci derecede rol oynaması, siyasal aktörlerin medyayla olan ilişkileri ve siyasetin magazinleșmesi 'siyasetin medyatikleștirilmesi' başlığı altında; yeni iletişim teknolojileri, modern kampanya teknikleri, artan kampanya giderleri, siyasal danışmanlar/ajanslar, negatif ve şov tipi kampanyalar 'siyasetin profesyonelleştirilmesi' başlığı altında; ideolojisizleştirme/depolitizasyon/siyasi çözülme, seçim partileri, partilerin yurttaşlara ilgisiz kalışı ve bağların kopması ise 'kitle partileri ve depolitizasyon' başlı̆̆ altında ele alınmıştır. Dolayısıyla bu çalışmada, siyasal iletişimin Amerikanlaşması 5 ana başlık altında incelenerek bir ülkedeki siyasal iletişimin ne denli Amerikanlaştığı bu başlıklara bakılarak değerlendirilecektir. Bu çerçevede tablo 1'de siyasal iletişimdeki Amerikanlaşmayı ortaya koyan ana ve alt başlıklar verilmiştir. 
Tablo 1: Siyasal İletişimdeki Amerikanlaşmayı Gösteren Kriterler

\begin{tabular}{|c|c|c|c|c|}
\hline $\begin{array}{c}\text { Siyasetin } \\
\text { Bilimselleştirilmesi }\end{array}$ & $\begin{array}{c}\text { Siyasetin } \\
\text { Kişiselleştirilmesi }\end{array}$ & $\begin{array}{c}\text { Siyasetin } \\
\text { Medyatikleştirilmesi }\end{array}$ & $\begin{array}{c}\text { Siyasetin } \\
\text { Profesyonelleştirilmesi }\end{array}$ & $\begin{array}{l}\text { Kitle Partileri ve } \\
\text { Depolitizasyon }\end{array}$ \\
\hline $\begin{array}{c}\text { - Kamuoyu } \\
\text { Yoklamaları } \\
\text { - Akademik } \\
\text { Araştırmalar } \\
\text { ve Raporlar } \\
\text { - Uzman } \\
\text { Görüşleri } \\
\text { - Teknik ve } \\
\text { İstatistiksel } \\
\text { Bilgiler }\end{array}$ & $\begin{array}{c}\text { • Siyasetçinin } \\
\text { Kimliği/Kişiliği } \\
\text { • Siyasetçilere } \\
\text { Takılan Lakaplar } \\
\text { • Parti Yerine } \\
\text { Lider Algısı } \\
\text { • İmajların } \\
\text { Politikanın Önüne } \\
\text { Geçmesi } \\
\text { • Siyasilerin } \\
\text { Özel Yaşantısı }\end{array}$ & $\begin{array}{c}\text { • Siyasetin } \\
\text { Eğlencelik Hale } \\
\text { Getirilmesi } \\
\text { • Siyasetin } \\
\text { Magazinelleştirilmesi } \\
\text { • Siyasal Haberlerin } \\
\text { Seyirlik Spor } \\
\text { Müsabakaları } \\
\text { Şeklinde Sunulması } \\
\text { • Siyasetin } \\
\text { Popülerleştirilmesi } \\
\text { • Siyasetçilerin } \\
\text { Starlaştıılması } \\
\text { • Medyanın } \\
\text { Bir Güç Odağı } \\
\text { Haline Gelmesi }\end{array}$ & $\begin{array}{c}\text { • Uzmanların/ } \\
\text { Danışmanların ve Reklam } \\
\text { Ajanslarının Faaliyetleri } \\
\text { • Kampanya Stratejileri } \\
\text { • Negatif Siyasal } \\
\text { Kampanyalar } \\
\text { • Şov / Gösteri Tipi } \\
\text { Kampanyalar } \\
\text { - Siyasal Kampanya } \\
\text { ve Reklamlar } \\
\text { • Bir Örnek Olarak } \\
\text { Amerikanlaşan Avrupa } \\
\text { Kampanyalarının } \\
\text { Türkiye'de Kullanımı } \\
\text { • Kampanyalarda } \\
\text { Teknolojinin Kullanımı } \\
\text { • Kampanya } \\
\text { Masraflarının Artması }\end{array}$ & $\begin{array}{c}\text { • Zayıflayan } \\
\text { Siyasal Parti- } \\
\text { Yurttaş Ilişkileri } \\
\text { ve Kitle Partileri } \\
\text { • Benzeşen Partiler } \\
\text { • İdeolojisizleştirme } \\
\text { • Vaatler ve } \\
\text { Depolitizasyon } \\
\text { • Negatif } \\
\text { Kampanyalar ve } \\
\text { Kararsız Seçmen }\end{array}$ \\
\hline
\end{tabular}

\subsection{Siyasetin Bilimselleştirilmesi}

Siyasal iletişim, doğası gereği ilişki içerisinde bulunduğu siyaset bilimi, sosyoloji, sosyal antropoloji, sosyal psikoloji, tarih, halkla ilişkiler, iletişim, propaganda ve pazarlama gibi bilimlerle birlikte çalışmakta ve bu bilimler ışığında ağırlıklı olarak kitle iletişim araçları üzerinden icra edilmektedir. Bahsedilen bilimler üzerinden gerçekleştirilen iletişim biçimleri sayesinde siyasal iletişim bugün için bilimsel bir araştırma sahası olarak değerlendirilmektedir. Ancak siyasetin bilimselleştirilmesindeki amaç Mancini ve Swanson'nun da (1996, s. 15) belirttiği gibi, yararlı alternatif kamu politikaları bulmak/ üretmek değildir. Amaç daha iyi bir kampanya süreciyle seçimleri kazanmaktır. Bu amaç, parti örgütlerinin zayıflaması ve siyasal sistemde görülen değişikliklerin kaçınılmaz bir sonucu gibi görünmektedir.

Siyasetin bilimselleştirilmesine ilişkin yargıyı, iki alt başlık içinde değerlendirmek mümkündür. Bunlardan birincisi, siyasal iletişim uzmanlarının, akademisyenlerin görüşlerinin önemsenmesi, ikincisi ise kamuoyu yoklamalarının ulusal basın tarafından sık sık gündeme getirilerek (Köker ve Kejanlıŏlu, 2004, s. 50), seçmen tercihlerinin biçimlendirilmesi açısından bilimsel çalışmalardan faydalanılması sonucunda kampanyaların teknik bir bilgi birikimiyle yoğrulmasıdır. Kamuoyu araștırmaları, toplumun tamamının veya belirli kesimlerinin bir sorun karşısındaki tutum ve düşüncelerini ortaya çıkarmak için yapılmaktadır.

Siyasal iletişimimin bilimselleştirilmesindeki temel nokta, seçmeni ikna etmek üzere hazırlanan kampanyalardaki etkinin artırılması adına bilim insanlarından, bilimsel araştırma verilerinden, uzmanlardan maksimum düzeyde faydalanılması, hatta kampanyanın doğrudan bu bağlamda kurgulanmasıdır.

\subsection{Siyasetin Kişiselleştirilmesi}

Günümüzde, siyasal partiler eski güç ve otoritesini yavaş yavaş kaybederken, siyasetçiler ise güçlenerek partilerden daha etkin ve etkili hale gelmektedirler. Kitlelerin partiler 
yerine siyasetçilerin etrafında toplanmasıyla, bireysel siyaset daha da ön plana çıkmakta ve bu da siyasetin kișiselleștirilmesine neden olmaktadır (Mancini and Swanson, 1996, s. 10). Siyasetin kişiselleștirilmesi sürecinde, kurumsallaşmış olan köklü siyasi partilerin/ grupların yerine siyasal aktörler/kişiler geçmektedir. Bu bağlamda seçim kampanyası boyunca sadece siyasal parti liderlerinin seçime gireceğini düşünmeye sevk edecek bir yoğunlukta, liderlerin etrafında kurulan bir dizi ilişki gündeme taşınmaktadır.

Siyasetin kişiselleştirilmesi, bugüne kadar alışılagelmiş şekilde partilerin siyasal pratiklerinin yerine kişisel figürlerin geçmesidir. Böylelikle, Max Weber'in modern demokrasiler için gerekli gördüğü 'karizmatik otorite' ile donatılmış liderliğin benimsetilmesi daha kolaylaşmakta ve bu doğrultuda son yıllarda kampanya yöneticileri tarafından ciddi çalışmalar yapılmaktadır (Köker ve Kejanlıoğlu, 2004, s. 44). Bu amaçla adayların imajını artırma, onu mitleştirme ve bir sembol haline getirmek için tanıtım yöntem ve teknikleri kullanılmakta (McNair, 2003, s. 103), siyasal aktörler biricik olarak tanımlanan özellikleri çerçevesinde olumlayıcı lakaplarla anılarak, kişisel imajlarının daha sağlam bir zemine oturtulmasına çalışılmaktadır. Bu bağlamda siyasal iletişimin kişiselleştirilmesi siyasetçinin kişiliği, siyasetçiyle özdeşleşmiş lakaplar, siyasetçinin her anlamda partiden daha ön planda yer alması ve önemsenmesi, siyasetçinin planlanmış bir imajla seçmene sunulması ve özel yaşantısı gibi konuları ifade etmektedir.

\subsection{Siyasetin Medyatikleştirilmesi}

Medya, siyasal arenada bir güç odağı olarak, kendi özerkliğini sürekli yeniden kurma eğilimindedir. Hem anaakım iletişim araștırmalarında hem de eleştirel yaklaşımlarla yapılan araştırmalarda medya, toplumsal olarak 'diğer güç merkezleriyle karşılıklı maddi ve sembolik alışveriş içindeki güç merkezi' şeklinde tanımlanmaktadır (Köker ve Kejanlığlu, 2004, s. 45-63). Medyanın politik rolünün, gün geçtikçe kapsam ve amaç olarak genişlediği ve bu araçların, politik yaşamın sistem dışı bir vasıtası olmaktan çıkarak, aktif bir katılımcısına dönüștüğü öne sürülmektedir. 'Medya vasıtasıyla politika yapmak' olarak adlandırılan bu yeni toplumsal dönem, gerek politik mesajlarını kamuya iletme peşinde koşan politikacıları, gerekse politik denetim, haber alma ve idareyi etkileme faaliyetlerini sürdürebilme çabasındaki seçmenleri, kitle iletişim araçlarına (medyaya) sıkı biçimde bağımlı hale getirmiștir (Oktay, 2002, s. 10). Bu nedenle siyaset, medya sisteminin etkisi altına girer girmez önemli ölçüde değişmektedir. Siyaset kendi benliğini kaybetmemekte, fakat medya sisteminin kurallarına bağlı hale gelmektedir. $\mathrm{Bu}$ şekilde medya sisteminin mantığı siyaseti sömürgeleştirirken, sadece siyasalın betimleme şeklini ya da diğer sistemlerle olan ilişkisini yeniden yapılandırmamaktadır. Aynı zamanda medya, süreci üretici düzeyinde yani siyasal alanın benzersiz bir yaşam biçimi olarak ortaya çıktığı düzeyde de etkilemektedir. Medyanın da etkisiyle siyaset günümüzde, eğlencelik olarak canlı, parıltılı, hatta abartılı bir gösteri olma eğilimindedir. Kısaca siyaset, her geçen gün biraz daha medyatikleştirilmektedir (Tokgöz, 2008, s. 328-329).

Siyasal aktörlerin söylemlerindeki sansasyonellikleri, üslupları, sertlikleri ve çarpıcılıkları, atışmaları medyanın gündemini oluşturmakta; bu gündem üzerinden siyasal aktörleri analiz eden yayınlar/programlar, siyasetçileri magazin programlarındaki top modellere, film yıldızlarına, dizi oyuncularına, pop starlara benzeterek, siyaseti giderek artan bir oranda magazinelleștirmekte ve medyatikleștirilmektedir. $\mathrm{Bu}$ dönüșümde siyasal aktörlerin medyaya olan ilgisi kadar, medyanın da siyasete olan düşkünlügünün de etkisi bulunmaktadır. Medya, siyaseti popülerleştirmekte; magazinel bir hale getirerek eğlencelik bir şova dönüştürmekte, yarattığı imajlarla da ortaya çıkarttığı siyasal 
aktörelerin bu şovda starlaşmasını izleyicilere sunmaktadır. Siyasal aktörlerin birer 'film aktörü' gibi starlaşması ve kitle iletişim araçları tarafından popüler imajlar şeklinde sunulması, siyasal iletişimin medya tarafından magazine dönüştürüldüğünün diğer bir kanıtıdır. Medyayla aracılanan siyaset, bir tür gösteriye/şova dönüşmüş durumdadır.

İzleyicinin dikkatini dağıtmamak için haberlerin kısa tutulması, bol miktarda görselin kullanımıyla anlatımın sadeleştirilerek basitleștirilip görselleştirilmesi, haber içeriğindeki konu çeşitliliği ve en taze dedikoduların sunumu, magazin programların karakteristik özelliklerini oluşturmaktadır. Magazin programlarının konuyu basite ve kolaya indirgeyen bu özellikleri, zamanla haber programlarına da sirayet ederek, haberleri anlama ve algılama bakımından izleyicilere kolaylık sağlamayı amaçlamıştır. Bu bağlamda siyasal haberlerin söylem ve içeriği basitleştirilmiş, siyaset eğlencelik bir konu haline getirilmiş, siyasal haberler magazin temalı haberlere dönüșmüş ve bütün bunların sonucu olarak da haber içerisindeki siyasal aktörler ve partiler kadar ideolojiler de magazinelleşerek, basitleşerek ağırlığını kaybetmiştir. Siyasetin eğlencelik bir malzemeye dönüştürülerek, haber programlarından magazin programlarına kadar pek çok yerde siyasete dair konuların işlenmesi, siyasetin içini boşaltmış, sulandırmış ve ciddiyetten uzaklaştırmıştır. Bu tür programlar infotainment (eğlenceli haber) ve politainment (eğlencelik siyaset) olarak siyasi aktörleri ve partileri daha da magazinel ve medyatik hale getirmektedir. Medyanın seçim kampanyalarında önemli ve başat bir rol üstlenmesi, kampanyalarla birlikte siyasetinde biçimini değiştirmiş, siyaseti medyatikleștirilmiştir.

\subsection{Siyasetin Profesyonelleştirilmesi}

Siyasal iletişimin profesyonelleşmesinde kampanya danışmanlarının ve ajansların büyük önemi bulunmaktadır. Antik çağdan beri siyasal kampanyalar hep danışmanlara ihtiyaç duymuş, bu danışmanlar başlangıçta parti içinden ya da dışından gönüllüler olarak ortaya çıkarken, sonraları ise ücretli profesyonel çalışanlar olarak devam etmiştir. Bugün her siyasal kampanyanın başında gördügüumüz siyasal danışmanlara, ilk olarak John Adams ve Thomas Jefferson'ın kampanya süreçlerinde ABD'de rastlanmaktadır. Bu kampanya sürecindeki danışmanlar, adaylara konuşmaları hakkında tavsiyede bulunan, basılı materyalleri dağıtan, demeçler veren ve oy toplamaya çalışan gönüllüler olarak karşımıza çlkmaktadır (Thurber, 2000, s. 1). Geçmişte siyasal danışmanlar, kurumsal bilgilerini, politik uzmanlıklarını veya konuşma-yazma yeteneklerini partilere/adaylara sunarak siyasal kampanyalarda görev almışlar, daha sonraki süreçte yetişen yeni uzmanlarsa medya ve ikna edici iletişim stratejileri üzerine olan eğitimleriyle, siyasi aktörlerin dikkatini çekmeyi başarmışlardır (Blumler ve Kavanagh, 1999, s. 213).

Siyasal iletişimin profesyonelleşmesinde iki nokta dikkati çekmektedir. Birincisi, merkezi planlama ve tüm kampanya iletişim faaliyetlerinin bütünleşik iletişim stratejileri olarak ticari halkla ilişkiler ve reklam kampanyalarının dokusunu takip etmiş olmasıdır. İkincisi ise halkla ilișkiler, pazarlama, reklam gibi alanlarda profesyonel olmayan parti çalışanları yerine konularında uzman olan kişilerle çalışılmasıdır (Esser, Reinemann, Fan, 2000, s. 212). Bu bağlamda günümüzde postmodern kampanyalarda görev alan siyasal danışmanlar reklam, kamuoyu, pazarlama ve stratejik haber yönetimi gibi konularda uzman, profesyonel kişilerden oluşmaktadır. Siyasal kampanya danışmanları ya da kampanyayı yürüten ajanslar, siyasete olan etkileriyle siyasal aktörlere denk bir duruma gelmekte ve kampanyanın yürütülmesi süresince parti içinde daha önemli bir rol üstlenerek, halk üzerinde daha etkili olmaktadırlar (Norris, 2003, s. 140). Siyasal iletişimde bu profesyonel anlayışın yükselişiyle birlikte Amerika ve Avrupa'da pek çok siyasi parti 1970’lerin sonları itibarı ile seçim öncesinde uluslararası reklam ajansları, 
siyasal danıșmanlarla birlikte seçim kampanyaları hazırlamaya başlamışlardır (Mattelart, 1995, s. 36-39). Özellikle 90'lı yıllar gerek ABD'de gerekse ABD dışındaki ülkelerde seçim sürecinde siyasal iletişim danışmanlarının bariz bir şekilde anahtar rol oynadığı yıllar olarak bilinmektedir (Negrine and Papathanassopoulos, 1996, s. 50).

\subsection{Seçim Partileri ve Depolitizasyon}

Siyasal bir amaçla halkı yönetmek üzere ortaya çıkan örgütlü gruplar olan siyasal partilerin yaptıkları tüm faaliyetlerde, kurdukları tüm ilişkilerde siyasal çıkar aranmaktadır. $\mathrm{Bu}$ nedenle siyasal partilerin yapacakları her türlü iletişim, siyasal iletişimin en dar anlamı ile de tanımlansa, siyasal iletişim içinde yer almaktadır (Aziz, 2007, s. 20). Siyasal partiler, siyaset kurumlarıyla yurttaşlar arasında bağ kuran politikalarla kitleleri buluşturan bir misyonu üstlenmektedir. Ancak siyasal iletişimde son yıllarda yaşanan gelişmeler, siyasal partilerde de bir çerçeve değişimi yaşanmasına neden olmuş, yurttaşlarla iletişim ve ilişki biçimleri değişmiştir. Siyasal adaylarla olan bireysel ilişkilerine göre tercihlerini yapan seçmenlerle parti organları arasındaki geleneksel ideolojik ve güvene dayalı olan karşılıklı bağlarda yavaş yavaş bir kopma gerçekleşmektedir (Mancini and Swanson, 1996, s. 14). Poggi de (2008, s. 187) benzer bir şekilde, çok partililiğin liberal-demokratik sistemin anlamlı ve önemli bir boyutunu oluşturduğunu, ancak liberal-demokratik toplumlarda giderek büyüyen depolitizasyon meselesine artık partilerin tek bașına çare olamayacaklarını ifade etmektedir.

Siyasal alanda seçmenlerin depolitize olması, bir noktada iktidarların da rıza üretimini kolaylaştırması sebebiyle iktidara ve siyasal partilere avantajlar sağlamaktadır. İktidarlar, kitle iletişim araçları -medya- üzerinden geçerek olumsuz durumlar karşısında gerçekleştirdikleri kamusal senaryolarla gündemi yönlendirme, bunalımı yaygınlaştırma, bilgisizleștirme, normalleștirme, umut geliștirme/kırma, alternatifsizleștirme, sivil itaatsizliği kırma, siyasetsizleștirme (Damlapınar, 2005, s. 124-126), ideolojisizleștirme, depolitize etme gibi unsurlarla kitlelerin iknasını daha kolay hale getirmektedir. Ayrıca, kitle iletişim araçlarının siyasal iktidarla ve sermayeyle özel ilişkiler içerisine girmesi, basın özgürlügünü engellediği gibi 'depolitize olma', 'özel yaşama müdahale etme' ve 'magazinleşme' süreçlerinin de yaşanmasına zemin hazırlamaktadır (Işılk, 2005, s. 85).

Modernleşmeyle birlikte ortaya çıkan bireyselleşme süreci, insanların toplum ve siyasete olan aidiyetlerini silikleştirmekte, bu durum siyasal partileri istikrarsızlaştırarak, bireylerin parti bağlılıklarına ciddi zarar vermektedir. Sonuç olarak yaşanan parçalanma ve bölünmeler, siyasal partileri zayıf ya da tutarsız ideolojik temelli, çerçevelerini yitirmiş, parçalı ve çoğulcul örgütler haline getirmektedir (Beck, 1999, s. 217-220). Modern seçim kampanyalarının da etkisiyle parti-seçmen ilişkisinde yaşanan değişimlerle birlikte partiler, ideolojik temellerini kaybederek daha fazla seçmene hitap etmeye çalışmakta ve ortaya geleneksel örgütlü partilerden oldukça farklı bir biçimde 'seçim partileri', 'kanaat partileri', 'çoğul toplayıcı partiler', 'sepet partileri' ya da 'kitle partileri' olarak adlandırılan partiler çıkmaktadır (Mancini and Swanson, 1996, s. 9-10).

Partilerin kitle partilerine dönüşmesiyle de yurttaşların siyasal partilerle olan bağları, demokratik kitle örgütleri, baskı grupları ve sendika örgütlenmeleri içindeki yerleri/ yersizlikleri, sivil toplum örgütlerinin içindeki etkinlikleri hiç gündeme getirilmemekte, yurttaşlar adeta bireysel tercihleriyle baş başa kalmış birer tüketici konumunda temsil edilmektedirler (Köker ve Kejanlıoğlu, 2004, s. 61). Amerikanlaşan siyasal kampanyalarda görülen bu durum, seçmenin yurttaşlıktan izleyiciliğe doğru bir geçiş yaşamasına neden 
olmakta (Mancini and Swanson, 1996), seçmenler partiden ve temsil ettiği ideolojik bağlılıklardan koparak kısmen depolitize olmakta, siyasal bir çözülme yaşamaktadır.

\section{Araştırma ve Bulgular}

Siyasal iletişimin Amerikanlaşması bağlamında gazete metinleri üzerinden incelediğimiz Ak Parti'nin 2002, 2007 ve 2011 seçim kampanyalarındaki Amerikanlaşmaya dair tespit edilen veriler seçim dönemlerine göre sırasıyla aşağıda sunulmuştur.

2002 Genel Seçimi için değerlendirmeye alınan 3 gazetede (Hürriyet, Posta, Sabah) 15 günlük süre boyunca toplam 449 adet siyasal haber/köșe yazısı/makale/röportaj incelenmiş, bu metinlerden 76 tanesi Ak Parti ve seçimle ilgili olmaması sebebiyle değerlendirme dışı bırakılmıştır. Geriye kalan 373 adet haber/köşe yazısı/makale/ röportaj, Ak Parti ve seçimlerle ilişkili olması sebebiyle değerlendirmeye alınmış, değerlendirme sonucu bu metinlerin 202 tanesinde Amerikanlaşma kriterlerine rastlanmazken, 171 metinde en az bir tane Amerikanlaşma kriteri saptanmıștır. Amerikanlaşma kriterine rastlanan 171 metinde toplam 257 ayrı Amerikanlaşma unsuru tespit edilmiștir. En fazla Amerikanlaşma kriteri, 65 metinde 123 unsurla Hürriyet gazetesinde tespit edilirken, Hürriyet gazetesini 57 metinde 68 unsurla Sabah gazetesi takip etmiş, üçüncü sırada da 49 metinde 66 unsurla Posta gazetesi yer almıştır.

Tablo 2: 2002 Yılı Seçim Dönemine Ait Gazetelerde Bulunan Amerikanlaşma Kriterlerinin Dağılımı

\begin{tabular}{|l|c|c|c|c|c|c|c|}
\hline & \multicolumn{7}{|c|}{ Incelenen Gazeteler } \\
\hline \multirow{2}{*}{$\begin{array}{l}\text { Tespit Edilen } \\
\text { Amerikanlaşma Kriterleri }\end{array}$} & \multicolumn{2}{|c|}{$\begin{array}{c}\text { Hürriyet } \\
\text { (123 Unsur) }\end{array}$} & \multicolumn{2}{|c|}{$\begin{array}{c}\text { Posta } \\
\text { (66 Unsur) }\end{array}$} & $\begin{array}{c}\text { Sabah } \\
\text { (68 Unsur) }\end{array}$ & $\begin{array}{c}\text { Toplam } \\
\text { Kriter } \\
\text { Sayısı }\end{array}$ \\
\cline { 2 - 9 } & $\begin{array}{c}\text { Kriter } \\
\text { Sayısı }\end{array}$ & $\begin{array}{c}\text { Yüzde } \\
\%\end{array}$ & $\begin{array}{c}\text { Bulunan } \\
\text { Kriter } \\
\text { Sayısı }\end{array}$ & $\begin{array}{c}\text { Yüzde } \\
\%\end{array}$ & $\begin{array}{c}\text { Bulunan } \\
\text { Kriter } \\
\text { Sayısı }\end{array}$ & $\begin{array}{c}\text { Yüzde } \\
\%\end{array}$ & \\
\hline Bilimselleştirilme & 27 & $\% 21,95$ & 10 & $\% 15,15$ & 9 & $\% 13,23$ & 46 \\
\hline Profesyonelleştirilme & 16 & $\% 13,00$ & 14 & $\% 21,21$ & 12 & $\% 17,64$ & 42 \\
\hline Medyatikleştirilme & 47 & $\% 38,21$ & 22 & $\% 33,33$ & 25 & $\% 36,76$ & 94 \\
\hline Kişiselleştirilme & 29 & $\% 23,57$ & 15 & $\% 22,72$ & 15 & $\% 22,05$ & 59 \\
\hline $\begin{array}{l}\text { Kitle Partileri ve } \\
\text { Depolitizasyon }\end{array}$ & 4 & $\% 3,25$ & 5 & $\% 7,57$ & 7 & $\% 10,29$ & 16 \\
\hline TOPLAM & 123 & $\% 100$ & 66 & $\% 100$ & 68 & $\% 100$ & 257 \\
\hline
\end{tabular}

2007 Genel Seçimi için değerlendirmeye alınan 3 gazetede (Hürriyet, Posta, Star) toplam 521 adet siyasal haber/köșe yazısı/makale/röportaj incelenmiş, bu metinlerden 118 tanesi Ak Parti ve seçimle ilgili olmaması sebebiyle değerlendirme dışı bırakılmıştır. Geriye kalan 403 adet haber/köșe yazısı/makale/röportaj, Ak Parti ve seçimler ilişkili olması sebebiyle değerlendirmeye alınmış, değerlendirme sonucu bu metinlerin 200 tanesinde Amerikanlaşma kriterlerine rastlanmazken, 203 metinde en az bir tane Amerikanlaşma kriteri saptanmıştır. Amerikanlaşma kriterine rastlanan 203 metinde, toplam 302 ayrı Amerikanlaşma unsuru tespit edilmiştir. En fazla Amerikanlaşma kriteri 91 metinde 152 unsurla, 2002 yılındaki gibi yine Hürriyet gazetesinde tespit edilirken, Hürriyet gazetesini 67 metinde 91 unsurla Star gazetesi takip etmiş, üçüncü sırada da 45 metinde 59 unsurla Posta gazetesi yer almıştır. 
Tablo 3: 2007 Yılı Seçim Dönemine Ait Gazetelerde Bulunan Amerikanlaşma Kriterlerinin Dağılımı

\begin{tabular}{|l|c|c|c|c|c|c|c|}
\hline & \multicolumn{7}{|c|}{ Incelenen Gazeteler } \\
\hline \multirow{2}{*}{$\begin{array}{l}\text { Tespit Edilen } \\
\text { Amerikanlaşma Kriterleri }\end{array}$} & \multicolumn{2}{|c|}{$\begin{array}{c}\text { Hürriyet } \\
\text { (152 Unsur) }\end{array}$} & \multicolumn{2}{|c|}{$\begin{array}{c}\text { Posta } \\
\text { (59 Unsur) }\end{array}$} & $\begin{array}{c}\text { Star } \\
\text { (91 Unsur) }\end{array}$ & $\begin{array}{c}\text { Toplam } \\
\text { Kriter } \\
\text { Sayısı }\end{array}$ \\
\cline { 2 - 9 } & $\begin{array}{c}\text { Kulunan } \\
\text { Kriter }\end{array}$ & $\begin{array}{c}\text { Yüzde } \\
\text { Sayısı }\end{array}$ & $\begin{array}{c}\text { Bulunan } \\
\text { Kriter } \\
\text { Sayısı }\end{array}$ & $\begin{array}{c}\text { Yüzde } \\
\%\end{array}$ & $\begin{array}{c}\text { Bulunan } \\
\text { Kriter } \\
\text { Sayısı }\end{array}$ & $\begin{array}{c}\text { Yüzde } \\
\%\end{array}$ & \\
\hline Bilimselleştirilme & 25 & $\% 16,44$ & 10 & $\% 16,94$ & 16 & $\% 17,58$ & 51 \\
\hline Profesyonelleştirilme & 46 & $\% 30,26$ & 16 & $\% 27,11$ & 26 & $\% 28,57$ & 88 \\
\hline Medyatikleştirilme & 36 & $\% 23,68$ & 15 & $\% 25,42$ & 31 & $\% 34,06$ & 82 \\
\hline Kişiselleştirilme & 25 & $\% 16,44$ & 11 & $\% 18,64$ & 12 & $\% 13,18$ & 48 \\
\hline $\begin{array}{l}\text { Kitle Partileri ve } \\
\text { Depolitizasyon }\end{array}$ & 20 & $\% 13,15$ & 7 & $\% 11,86$ & 6 & $\% 6,59$ & 33 \\
\hline TOPLAM & 152 & $\% 100$ & 59 & $\% 100$ & 91 & $\% 100$ & 252 \\
\hline
\end{tabular}

2011 Genel Seçimi için değerlendirmeye alınan 3 gazetede (Hürriyet, Posta, Zaman) toplam 312 adet siyasal haber/köșe yazısı/makale/röportaj incelenmiş, bu metinlerden 43 tanesi, Ak Parti ve seçimle ilgili olmaması sebebiyle değerlendirme dışı bırakılmıştır. Geriye kalan 269 adet haber/köşe yazısı/makale/röportaj, Ak Parti ve seçimlerle ilişkili olması sebebiyle değerlendirmeye alınmış, değerlendirme sonucu bu metinlerin 132 tanesinde Amerikanlaşma kriterlerine rastlanmazken, 137 metinde en az bir tane Amerikanlaşma kriteri saptanmıştır. Amerikanlaşma kriterine rastlanan 137 metinde toplam 254 ayrı Amerikanlaşma unsuru tespit edilmiştir. En fazla Amerikanlaşma kriteri 55 metinde 104 unsurla Zaman gazetesinde tespit edilirken, Zaman gazetesini 43 metinde 78 unsurla Posta gazetesi takip etmiş, üçüncü sırada da 2002 ve 2007 seçimlerinde en fazla Amerikanlaşma kriteri tespit edilen Hürriyet gazetesi, 39 metinde 72 unsurla son sırada yer almıştır.

Tablo 4: 2011 Yılı Seçim Dönemine Ait Gazetelerde Bulunan Amerikanlaşma Kriterlerinin Dağılımı

\begin{tabular}{|l|c|c|c|c|c|c|c|}
\hline \multirow{2}{*}{$\begin{array}{l}\text { Tespit Edilen Amerikanlaşma } \\
\text { Kriterleri }\end{array}$} & \multicolumn{2}{|c|}{$\begin{array}{c}\text { Hürriyet } \\
\text { (72 Unsur) }\end{array}$} & \multicolumn{2}{|c|}{$\begin{array}{c}\text { Posta } \\
\text { (78 Unsur) }\end{array}$} & \multicolumn{2}{c|}{$\begin{array}{c}\text { Zaman } \\
\text { (104 Unsur) }\end{array}$} & $\begin{array}{c}\text { Toplam } \\
\text { Kriter } \\
\text { Sayısı }\end{array}$ \\
\cline { 2 - 9 } & $\begin{array}{c}\text { Bulunan } \\
\text { Kriter } \\
\text { Sayısı }\end{array}$ & $\begin{array}{c}\text { Yüzde } \\
\text { \% }\end{array}$ & $\begin{array}{c}\text { Bulunan } \\
\text { Kriter } \\
\text { Sayısı }\end{array}$ & $\begin{array}{c}\text { Yüzde } \\
\%\end{array}$ & $\begin{array}{c}\text { Bulunan } \\
\text { Kriter } \\
\text { Sayısı }\end{array}$ & $\begin{array}{c}\text { Yüzde } \\
\%\end{array}$ & \\
\hline Bilimselleştirilme & 6 & $\% 8,33$ & 9 & $\% 11,53$ & 22 & $\% 21,15$ & 37 \\
\hline Profesyonelleştirilme & 18 & $\% 25,00$ & 25 & $\% 32,05$ & 25 & $\% 24,03$ & 68 \\
\hline Medyatikleştirilme & 17 & $\% 23,61$ & 15 & $\% 19,23$ & 33 & $\% 31,73$ & 65 \\
\hline Kişiselleştirilme & 27 & $\% 37,50$ & 23 & $\% 29,48$ & 19 & $\% 18,26$ & 69 \\
\hline $\begin{array}{l}\text { Kitle Partileri ve } \\
\text { Depolitizasyon }\end{array}$ & 4 & $\% 5,55$ & 6 & $\% 7,69$ & 5 & $\% 4,80$ & 15 \\
\hline TOPLAM & 72 & $\% 100$ & 78 & $\% 100$ & 104 & $\% 100$ & 254 \\
\hline
\end{tabular}

Yapılan incelemeler sonucunda, Amerikanlaşma kriterlerinin gazetelerde yer aldığı metin sayısı ve metinlerde görülme yoğunluğunun farklılık gösterdiği tespit edilmiștir. Örneğin, gazete metinlerinde rastlanan en fazla Amerikanlaşma, 2007 seçiminde toplam 203 metinde 302 unsurla gerçekleșirken değerlendirmeye alınan metin bașına düşen kriter sayısı (kriter yoğunluğu) \%74,93 şeklinde ölçülmüştür. Gazete metinlerindeki en az Amerikanlaşma ise 2011 seçiminde 137 metinde 254 unsurla saptanırken, değerlendirmeye alınan metin başına düşen kriter sayısı ise (kriter yoğunluğu) 2007 seçimlerinin üzerinde gerçekleşmiş ve \%94,42 şeklinde ölçülmüştür. 2002 seçiminde ise 
171 metinde 257 unsur tespit edilmesine karşın değerlendirmeye alınan metin başına düşen kriter yoğunluğu \%68,90 ile 2007 oranına yakın olduğu görülmüştür. Sonuçlara bakıldığında, incelenen metinlerde, 2002 ve 2007 seçimlerinde daha fazla sayıda metin Amerikanlaşma kriteri içerirken 2011 seçiminde ise Amerikanlaşma kriteri içeren haber sayısı azalmasına karşın metinlerindeki yoğunluğu artmıştır. Tablo 5'e bakıldığında metin sayısındaki değişimden bağımsız olarak kampanyalardaki Amerikanlaşma kriterlerindeki yoğunluğun (oranların) her seçim döneminde bir önceki döneme göre arttığı görülmektedir.

Tablo 5: Ylllara Göre Amerikanlașma Kriteri Tespit Edilen Metin ve Unsur Sayıları

\begin{tabular}{|l|l|l|l|l|l|}
\hline & $\begin{array}{l}\text { İncelenen } \\
\text { Toplam } \\
\text { Metin Sayısı }\end{array}$ & $\begin{array}{l}\text { Değerlendirmeye } \\
\text { Alınan “Ak Parti” ve } \\
\text { "Seçim" Anahtar } \\
\text { Kelimelerini Birlikte } \\
\text { İceren Toplam } \\
\text { Metin Sayısı }\end{array}$ & $\begin{array}{l}\text { Amerikanlaşma } \\
\text { Kriteri Görïlen } \\
\text { Metin SayıSı }\end{array}$ & $\begin{array}{l}\text { Amerikanlaşma } \\
\text { Kriteri Görülen } \\
\text { Metinlerde Tespit } \\
\text { Edilen Kriter SayıSı }\end{array}$ & $\begin{array}{l}\text { Değerlendirmeye } \\
\text { Alınan Metin } \\
\text { Başına Düşen } \\
\text { Amerikanlaşma } \\
\text { Unsuru Oranı }\end{array}$ \\
\hline 2002 & 449 & 373 & 171 & 257 & $\% 68,90$ \\
\hline 2007 & 521 & 403 & 203 & 302 & $\% 74,93$ \\
\hline 2011 & 312 & 269 & 137 & 254 & $\% 94,42$ \\
\hline TOPLAM & 1282 & 1045 & 511 & 813 & Ort. \% 77,79 \\
\hline
\end{tabular}

Yapılan incelemeler sonucunda gazetelerde en fazla yer alan Amerikanlaşma kriterinin 241 unsurla 'medyatikleştirilme' olduğu saptanırken, bunu sırasıyla 198 unsurla 'profesyonelleștirilme', 176 unsurla 'kișiselleștirilme', 134 unsurla 'bilimselleștirilme' takip etmiş, son sırada da 64 unsurla "kitle partileri ve depolitizasyon" kriteri görülmüştür.

Siyasal iletişimin Amerikanlaştığının göstergesi olduğunu iddia ettiğimiz tüm Amerikanlaşma kriterlerinin, Ak Parti'nin siyasal iletişim çalışmalarının gazetelere yansıyan haliyle farklı sayılarda yer aldığı görülmüștür. Söz konusu bu sayılar yıllara ve gazetelere göre değişiklik göstermiştir. Örneğin, Hürriyet gazetesinde 2002 seçimlerinde 'medyatikleştirilme' 47 unsurla en fazla saptanan kriterken, 2007 seçimlerinde 'profesyonelleștirilme' kriteri 46 unsurla, 2011 seçiminde ise 'kişiselleştirilme' 27 unsurla en fazla görülen kriter olmuştur. İncelenen tüm gazetelerde 'kitle partileri ve depolitizasyon' kriterinin, her seçim döneminde ve her gazetede en az saptanan kriter olduğu görülmüştür.

2002 ve 2007 seçimlerinde, siyasal iletişimin Amerikanlaşması çerçevesinde, diğer gazetelerden çok daha fazla metin ve kriter sayısı bulunduran Hürriyet gazetesi, 2011 seçimlerinde ise Amerikanlaşma kriterleri açısından son sırada yer almıştır. Bu çerçevede gazetenin yayın politikası üzerine yaptığımız incelemede, gazetenin 2002 ve 2007 seçim döneminde Ertuğrul Özkök'ün genel yayın yönetmenliğinde yayımlanırken, 29 Aralık 2009'da Ertuğrul Özkök'ün genel yayın yönetmenliğini Enis Berberoğlu'na devretmesiyle gazetenin 2011 seçiminde Berberoğlu'nun genel yayın yönetmenliğinde yayımlandı̆̆ı görülmüştür. 2002 ve 2007 seçim dönemindeki haberlerle, 2011 seçim dönemindeki haberlerin, Amerikanlaşma bağlamında farklılık göstermesinin sebebini, genel yayın yönetmenliğindeki değişim ve bu değişimin gazetenin yayın politikasına yansıması olarak değerlendirilmiştir.

\section{Sonuç}

Türkiye'deki siyasal iletişim çalışmalarının/kampanyaların Amerikanlaştığını iddia eden bu çalışmada, söz konusu Amerikanlaşma kriterleri açlklanarak bu kriterler doğrultusunda Ak Parti'nin 2002, 2007, 2011 genel seçimlerindeki kampanyalarının 
gazetelere yansıması incelenmiş ve gazetelerden elde edilen veriler ışığında siyasal iletişimdeki benzeşmenin/Amerikanlaşmanın ortaya konulmasına çalışılmıştır.

Yapılan incelemeler sonucunda, siyasal iletişimin Amerikanlaşması sürecinde sadece partilerin ya da siyasetçilerin tek başına etkili olmadığı görülmüştür. Her ne kadar parti ve siyasetçiler, Amerikanlaşma sürecinin güçlü belirleyicileri olsalar da bu sürecin tek belirleyicilerinin onlar olmadıkları, partilerin/siyasetçilerin yanı sıra, kampanya yöneticilerinin/profesyonellerin, medyanın/gazetecilerin ve vatandaşın da/seçmenin de siyasal iletişimin Amerikanlaşmasında etkili olduğu tespit edilmiştir.

Amerikanlaşma sürecindeki kilit rol partilere ve siyasetçilere aittir. Partiler/siyasetçiler kampanya süresince çalışacakları profesyonelleri seçmeleri, profesyonellerin yürütecekleri kampanyayı onaylamaları ve uygulamaları, profesyonellerin belirledikleri stratejiler doğrultusunda seçmene seslenmeleri ve bu doğrultuda medyaya malzeme vermeleri sebebiyle Amerikanlaşmadaki en büyük paya sahiptirler. Kısacası, Amerikanlaşmaya etki eden diğer yapılara partiler/siyasetçiler yön vermektedirler.

Siyasal iletişimin Amerikanlaşmasındaki ikinci etmen, kampanyayı yürüten profesyoneller/ajanslardır. Söz konusu kampanya yöneticileri, partiler için genellikle denenmiş, başarılı olmuş, popüler stratejiler hazırlamaktadırlar. Ayrıca, ABD'deki seçimlerinin büyük bir yarışa/çekişmeye sahne olması, kampanyalarda teknolojinin ve belirli yöntemlerin/tekniklerin kullanılması, seçimlerin siyasetçilerden çok kampanya yöneticilerinin savaşına dönüşmesi ve onların şovu haline gelmesi, diğer ülkelerdeki profesyonelleri de etkilemektedir. Bu nedenle profesyoneller, iyi örnek olarak görülen/ gösterilen ABD'deki kampanyalara benzer çalışmalar yapmak, kampanyaları birer şova dönüştürerek diğer ajanslardan farklılaşmak, dolayısıyla en başarılı ajans algısıyla bir sonraki seçim dönemine yatırım yapmak amacıyla Amerikanvari kampanyaları özellikle tercih etmektedirler. Bu durum, siyasal iletişimin/kampanyaların Amerikanlaşmasında profesyonellerin de/ajansların da ciddi etkisinin olduğunu göstermektedir.

Siyasal iletişimin Amerikanlaşması sürecindeki üçüncü etmen ise medyanın, partilerin/ siyasetçilerin kampanyalarını politikalarından daha fazla önemsemesi ve kampanyaları amacını aşan bir şekilde ekranlara/sayfalara/yayım mecralarına taşımasıdır. $\mathrm{Bu}$ çerçevede gazetecilerin, siyasetçilerin söylemlerini farklı konularla ilişkilendirerek bazen de konuları magazinelleştirerek haber yaptıkları görülmüştür. Yine benzer şekilde gazetelerde yer alan metinlerin genelinde, siyasilerin ne söylediklerinden çok nasıl söyledikleri ne anlattıklarından çok kime nasıl cevap verdikleri üzerine kurgulandığı tespit edilmiştir. Bu doğrultuda, Amerikanlaşma unsurlarının daha sansasyonel daha popüler olmaları sebebiyle, gazetecilerin daha fazla ilgisini çektiği görülmüştür. Bu noktada Encabo'nun (2002, s. 447), gazetelerin en sansasyonel başlıklar için yarışarak hedef kitlesi üzerinde doğrudan duygusal etki yaratmak amacıyla çalışan bir gösteri aracı haline geldiği iddiası, bu çalışmada yapılan saptamaları da doğrular niteliktedir.

Yukarıda anlatılanlar çerçevesinde, örneklem olarak seçilen gazetelerde yer alan metinler, medyanın genel olarak kampanyaların Amerikanvari, şov kısımlarıyla ilgilendiğini göstermektedir. Gazete metinlerinde Amerikanlaşma kriterlerinin ön plana çıkarılması, siyasetçilerin medyada yer alabilmek amacıyla bu doğrultuda söylem ve davranışlar sergilemesine neden olmuștur. Bu anlamda, medyanın da siyasal iletişimin/kampanyaların Amerikanlaşmasında etkili bir unsur olduğunun altını çizmek gerekmektedir. Yine benzer şekilde gazete haberlerinde partilerin reklam filmlerinden kampanya yönetimlerine, liderlerin yaptıkları miting sayılarından mitinge katılım sayılarına, parti şarkılarından 
parti sloganlarına kadar pek çok nokta değerlendirilerek, diğer partilerle karşılaştırmalı olarak ele alınmasına karşın, parti programlarının/politikalarının ya da ülke sorunlarının aynı ciddiyet ve sıklıkla değerlendirilmediği saptanmıştır. Bununla birlikte gazetelerde yer alan seçim haberlerinin, Amerika bașta olmak üzere Batı'lı ülkelerle kıyaslanarak değerlendirildiği görülmüştür.

Siyasal kampanyaların Amerikanlaşması sürecinin son halkasında ise seçmen/vatandaş yer almaktadır. Seçmenin, sürece katkısının pasif ve aktif olarak iki şekilde gerçekleştiği görülmüştür. Seçmen, söz konusu süreçte pasif olarak, medya tarafından kendine iletilen Amerikanlaşma unsurlarını sorgulamadan kabul etmekte ve onaylamaktadır. Medya, profesyoneller tarafindan hazırlanan Amerikan tarzı kampanya örneklerini uygulayan siyasetçilerin söylemlerini/davranışlarını/kampanyalarını haberleştirerek seçmene ulaştırmaktadır. Seçmen de söz konusu zincirin son halkası olarak, siyasilerin medya aracılığıyla kendilerine gönderdikleri iletileri pasif bir pozisyonda alarak, izlediği siyasal şovun bir parçası haline gelmekte, siyasal tartışmalara siyasilerin oluşturdukları ve içi boşaltılarak eğlencelik bir hale getirilmiș konular üzerinden katılmaktadır.

Seçmenin Amerikanlaşma sürecine aktif olarak katılımı ise arkadaş toplantıları, miting meydanları, sosyal medya gibi kendisini kısıtlamadan görüşlerini ifade edebildiği her ortamda, partisinin/liderinin söylemlerini/kampanya yöntemlerini aynı tonda ifade ederek Amerikanlaşmanın içselleştirilmesini, normalleştirilmesini ve yaygınlaştırılmasını sağlaması şeklinde ortaya çıkmaktadır. Seçmen, bazen daha da ileriye giderek söz konusu mecralarda yeni sloganlar, şarkılar, videolar, afişler, pankartlar vb. seçim materyalleri hazırlayarak partilerin mitinglerine/şovlarına katılmak suretiyle de sürece aktif olarak katkı sağlayabilmektedir. Dolayısıyla Amerikanlaşma süreci siyasetçilerden başlayarak sırasıyla profesyonelleri, medyayı ve son aşamada seçmeni içine alacak şekilde giderek genişleyen bir spirale dönüşmektedir.

Yukarıda tek tek sayılan ve birbirlerini temelden etkileyen söz konusu yapılar, kampanya süresince zincirleme bir etki ortaya çıkarmakta ve kampanyalar bu yapılar arasındaki ilişkilerle kısır bir döngüye girerek gittikçe daha fazla Amerikanlaşmaktadır. Partiler/ siyasetçiler medyada görünür olmak ve seçmende karşılık bulabilmek için profesyonellerle anlaşmakta/çalışmakta; siyasal kampanyaları hazırlayan profesyoneller daha fazla dikkat çekmek adına kampanyaları birer şova dönüştürerek partilerin/siyasetçilerin stratejilerini olabildiğince Amerikanlaştırmakta; hazırlanan stratejiler doğrultusunda, siyasilerin Amerikan tarzı söylem ve davranışları medyanın/gazetecilerin daha fazla ilgi göstermesine neden olmakta; dolayısıyla medya kampanyadaki Amerikanlaşma unsurlarını vurgulayarak/köpürterek daha da görünür hale getirmekte ve Amerikanlaşma unsurlarının ön plana çıktığı haberlerin seçmene ulaşmasını sağlamakta; seçmen de medyanın ve liderlerin etkisiyle sürece dahil olarak, liderin Amerikanlaşan söylem ve davranışlarını bazen alkışlayarak bazen de gazetelere yansıyan sokak röportajlarıyla, gazetelere gönderilen okuyucu mektuplarıyla, seçim meydanlarında açılan döviz ve pankartlarıyla bazen de herhangi bir sosyal ortamda aktif bir şekilde liderlerin söylem ve davranışlarını destekleyici bir tutumla ortaya çıkarak siyasal iletişimdeki Amerikanlaşmayı daha ileri boyutlara taşımaktadır.

Profesyoneller, Amerikan tarzı kampanyalarla kitleleri etkileyerek doğru bir strateji izlediklerini siyasilere gösterirken, siyasetçiler de seçmenin sürece dahil olmasıyla kampanyalarının gerçekten etkili olduğuna ve oy oranlarını artırdıklarına inanmaktadırlar. Diğer taraftan, seçmenin Amerikanlaşan seçim kampanyalarına daha 
fazla ilgi göstereceğini düşünen medya, siyasal kampanyaların Amerikanvari özelliklerine daha fazla yer vermekte; seçmen ise liderinin ardından giderek benzer şekildeki söylem ve davranışlarla ona destek olduğunu düşünmektedir. Dolayısıyla Amerikanlaşma sürecinin, farklı şekillerde devam eden bir domino etkisi yarattığı görülmektedir. Kısaca özetleyecek olursak, siyasal iletişimin Amerikanlaşması sürecinde partiler/siyasetçiler, profesyoneller, medya ve seçmen hem birbirini etkileyerek hem de birbirinden etkilenerek siyasal iletişimdeki Amerikanlaşmayı sürekli olarak artırmaktadırlar.

\section{Kaynakça}

Akdoğan, Y. (1995). Görsel İktidar. İstanbul: İnsan Yayınları.

Ansolabehere, S. and Iyengar, S. (1997). Going Negative: How Political Advertisements Shrink \& Polarize the Electroate. USA: The Free Press.

Aziz, A. (2007). Siyasal İletişim. Ankara: Nobel Yayınları.

Baudrillard, J. (1996). Amerika (Çev. Yaşar Avunç). İstanbul: Ayrıntı Yayınları.

Beck, U. (1999). Siyasallığın İcadı (Çev. Nihat Ülner). İstanbul: İletişim Yayınları.

Blumler, G. J. and Kavanagh, D. (1999). The Third Age of Political Communication: Influences and Features. Political Communication, 16(3), 209-230. Routledge.

Buchanan, I. B. (2005). Mediated Electoral Democracy: Campaigns, Incentives, and Reform. Lance W. Bennett, Robert M. Entman (Ed.), Mediated Politics: Communication in the Future of Democracy içinde (pp. 363-379). New York: Cambridge University Press.

Damlapınar, Z. (2005). İktidar ve Kitle İletişim Araçları Üzerinden Rıza Üretimi. Zülfikar Damlapınar (Ed.), Medya ve Siyaset Illişkileri Üzerine içinde (s.115-140). Ankara: Turhan Kitabevi.

Dursun, D. (2004). Siyaset Bilimi (2.b.). İstanbul: Beta Yayınları.

Duverger, M. (1964). Politikaya Giriş (Çev. Samih Tiryakioğlu). İstanbul: Varlık Yayınları.

Encabo, N. M. (2002). Gazetecilik Etiği ve Demokrasi (Çev. Ümit Hüsrev Yolsal). Süleyman İrvan (Der.), Medya Kültür Siyaset içinde (s. 443-464). Ankara: Alp Yayınevi, 2.b.

Esser, F., Reinemann, C., and Fan, D, (2000). Spin Doctoring in British and German Election Campaigns: How the Press is Being Confronted with a New Quality of Political PR. Europen Journal of Communication, 15(2), 209-239.

Graber, A. D. and Smith, M. J. (2006). Political Communication Faces the $21^{\text {st }}$ Century. Journal of Communication, 55 (3) 479-507.

Hallin, C. D. and Mancini, P. (2004). Americanization, Globalization and Secularization: Understanding the Convergence of Media Systems and Political Communication. Frank Esser, Barbara Pfetsch (Ed.), Comparing Political Communication: Theories, Cases and Challenges içinde (pp. 25-44). USA: Cambridge University Press.

Holtz-Bacha, Christina (2002). Professionalizm of Political Communication. Journal of Political Marketing, 1(4), 23-37.

Işık, M. (2005). Türkiye'deki İletişim Sisteminin Medya Siyaset İlişkilerine Yansımaları. Zülfikar Damlapınar (Ed.), Medya ve Siyaset İlişkileri Üzerine içinde (s. 77-91). Ankara: Turhan Kitabevi.

Kışlalı, A. T. (1997). Siyaset Bilimi (6.b.). Ankara: İmge Kitabevi. 
Köker, E. ve Kejanlıŏlu, B. (2004). 2002 Seçim Kampanyalarında Ulusal Basın. İletişim Araștırmaları Dergisi, 2(1), 41-72.

Lilleker, G. D. (2006). Key Concepts in Political Communication, London: Sage Publications. Mattelart, A. (1995). Beyin İğfal Şebekesi (Çev. Işın Gürbüz). İstanbul: Ayrıntı Yayınları.

McNair, B. (2003). An Introduction to Political Communication ( $3^{\text {th }}$ ed.). New York: Routledge.

Meyer, T. ve Hinchman, L. (2002). Medya Demokrasisi: Medya Siyaseti Nasıl Sömürgeleştirir (Çev. Ahmet Fethi). İstanbul: Türkiye İș Bankası Kültür Yayınları.

Mutlu, E. (2004). İletişim Sözlüğü (4.b.). Ankara: Bilim ve Sanat Yayınları.

Negrine, R. and Papathanassopoulos, S. (1996). The 'Americanization' of Political Communication: A Crituque. The Harvard International Journal of Press/Politics, $1(2), 45-62$.

Norris, P. (2003). A Virtuous Circle: Political Communications in Postindustrial Societies. New York: Cambridge University Press.

Novotny, Patrick (2000). From Polis to Agora: The Marketing of Political Consultants. The International Journal of Press/Politics, 5, 12-26.

Odabaşı, Y. (2009). Siyasal Pazarlama Uygulamalarına Yön Veren Dönüşüm ve Açılımlar. Abdullah Özkan (Der), Siyasetin İletişimi içinde (s. 33-52). İstanbul: Tasam Yayınları.

Oktay, M (2002). Politikada Halkla İlişkiler. İstanbul: Derin Yayınları.

Özkan, A. (2007). Siyasal İletişim Stratejileri (1.b.). İstanbul: Tasam Yayınları.

Poggi, G. (2008). Devlet Doğası, Gelişimi ve Geleceği (2.b.), (Çev. Aysun Babacan). İstanbul: İstanbul Bilgi Üniversitesi Yayınları No:164.

Mancini, P. and Swanson, L. D. (1996). Politics, Media and Modern Democracy: Introduction. David Swanson, Paolo Mancini (Ed.), Politics, Media and Modern Democracy: An International Study of Innovations in Electoral Campaigning and Their Concequences içinde (pp.1-21). London: Praeger Publishers.

Thompson, B. J. (2008). Medya ve Modernite (Çev. Serdar Öztürk). İstanbul: Kırmızı Yayınlarl.

Thurber, A. J. (2000). Introduction to the Study of Campaign Consultants. James A. Thurber, Candice J. Nelson (Ed.), Campaign Warriors: Political Consultants in Elections içinde (pp. 1 -9). Virginia: R.R. Donaly and Sons.

Tokgöz, O. (2008). Siyasal İletişimi Anlamak (1.b.). Ankara: İmge Yayınları.

Topuz, H. (1991). Siyasal Reklamcılık: Dünyadan ve Türkiye'den Örneklerle. İstanbul: Cem Yayınevi.

Uztuğ, F. (1996). Siyasi Pazarlama, Kamuoyu Oluşumu ve Kamuoyu Araştırmaları. Yeni Türkiye Dergisi, 11, 844-853. 


\title{
The Review of the AK Party's Political Communication Studies on the Newspapers in the Context of Americanization of Political Communication
}

\author{
Ahmet Öztekin (Asst. Prof. Dr.)
}

\section{Extended Abstract}

The race to prevalence in the ruler-ruled competition which dates back to the history of humanity has turned into a struggle for power between groups, which is performed within the framework of planned activities. The methods of reward and punishment, which emerged in different ways according to the conditions of the period, were frequently utilized in this struggle for power. The experiences and changes in social structure changed the methods and instruments in politics quantitatively and qualitatively as time passed and led to a new interpretation of politics. Therefore, the concept of political communication has emerged as a new topic in the relationship between ruler and ruled.

The concept of political communication has also changed and transformed over time in our world in which the only thing that does not change is the change itself. The United States, which emerged as a great power after World War II, became the dominant power and culture in the world by taking over the leadership of the world after the end of the Cold War in 1990. The reasons that the globalization continues at an increasing rate and the United States presents itself as an ideal example in economic, political, military and cultural terms as the leading force of globalization, lead to a process of Americanization throughout the world. The effect of Americanization also manifests itself intensively in the field of political communication, and it is observed that the practices of political communication around the world are increasingly similar to the campaigns in the USA. The relative wealth and mobility of political communication in the United States also attracts the attention of politicians in other countries and it is observed that there is an Americanization in the field of political communication as the practices of political communication are increasingly similar to the campaigns in America, despite the different political, cultural and social structures in the countries.

In this study, the Americanization of political communication is analysed within the framework of the phenomenon of Americanization, which started with the presentation of the USA as an ideal example in every field and increased with globalization. The phenomenon of the Americanization of political communication, which started to be seen in the European election campaigns in the 1960s and continues to increase today, given that this phenomenon causes Americanlike a similarity throughout the world and that the assumption that when Turkey is also affected by this analogy, an analysis was performed on the reflection of the Ak Party's political communication efforts to the newspapers, in the context of the Americanization of political communication.

Although there is a general consensus in the Americanization of political communication, there is no consensus in which criteria, factors and practices cause Americanization in political communication, in other words, on the point of Americanization; and different criteria are found in academic studies on this subject. As a result of the analyzes, although the Americanization criteria are handled under different names and titles, it is seen that the content of the Americanization is similar. 
Also, in this study, the Americanization criteria which were reached as a result of the above-mentioned analysis are categorized under 5 main topics. The technicalization and scientificization of politics are discussed under the topic of 'scientificization of politics'; image factor and personalization are discussed under the topic of 'personalization of politics'; the role of the media in the campaigns and the relations of the political actors with the media and the magazine's becoming a media are discussed under the topic of 'media mediation'; new communication technologies, modern campaign techniques, increasing campaign expenses, political consultants/agencies, negative and show-type campaigns are discussed under the topic of 'professionalization of politics'; the deideology/depoliticization/political dissolution, the election parties, the disinterest of the parties to the citizens and the break of ties are discussed under the topic of 'mass parties and depolitization'. Thus, in this study; The Americanization of political communication has been analyzed under 5 main topics and the extent to which political communication in a country has become Americanized has been evaluated by investigating at these topics.

The reflections of Ak Party's 2002, 2007 and 2011 general election campaigns on newspapers were analyzed in this study. As representing the printed press, the first three newspapers were chosen as samples for each election period. Accordingly; it was taken as a sample; Hürriyet, Posta and Sabah newspapers between 18 September 2002 and 2 November 2002 in the 2002 election; Hürriyet, Posta and Star newspapers, between 7 July 2007 and 21 July 2007, in the 2007 election; Hürriyet, Posta and Zaman newspapers, between 28 May 2011 and 11 June 2011, in the 2011 election. In the evaluation, all of the news reports, columns, articles, interviews, conversations and photo writings in the newspapers were included.

For the purposes of the study, the keywords of 'Ak Party' and 'election' texts which used together were searched in the selected newspapers. At the end of the search, a total of 1045 texts were identified, which consisted of 'Ak Party' and 'election' keywords, and the analysis was performed on these 1045 texts.

Because of the investigations of newspaper texts; content analysis and discourse analysis were chosen as the methods of the study. The data obtained from the newspaper texts as a result of the analysis were explained with a quantitative and qualitative interpretation within the framework of the Americanization of political communication. All messages identified in the newspapers were examined and the Americanization elements identified were grouped according to the topics mentioned above, within the framework of the selected keywords.

As a result of the analyses and evaluations, it was seen that all of the criteria that showed Americanization in political communication existed in Ak Party's political communication campaigns and these were reflected in the newspaper texts. It was found in the analysis performed on the Ak Party's example, that the Americanization in political communication did not originate solely from parties or politicians. Although the fact that parties and politicians are powerful determinants of the Americanization process, it was determined that they were not the sole determinants of this process and that the campaign managers/professionals, the media/journalists and the citizen/electorate were also influential in the Americanization of political communication.

The above-mentioned structures affecting each other fundamentally, create a chain effect during the campaign and campaigns are becoming more and more American by entering a vicious circle with the relationships between these structures. Parties/politicians agree to work with professionals in order to be visible in the media and to respond to voters; The 
professionals preparing the political campaigns turn the campaigns into shows to attract more attention; They form the strategies of parties/politicians as American as possible; In line with the strategies prepared, politicians' American style discourse and behavior causes the media / journalists to pay more attention; Therefore, the media makes the campaign more visible by emphasizing/bubbling the elements of Americanization in the campaign and they help the voters reach the news where the elements of Americanization come to the fore; Voters are also involved with the influence of the media and leaders and the American rhetoric and behavior of the leader is sometimes applauded, sometimes with street interviews reflected in the newspapers, readers' letters which are sent to newspapers, foreign exchange and banners which are opened in the election plazas take Americanization further. And sometimes it appears as an active supportive of the discourse and behavior of the leaders in any social environment and takes Americanization in political communication to a higher level.

Keywords: Political Communication, Americanization of the Political Communication, Ak Party, 2002 General Election, 2007 General Election, 2011 General Election. 
